\title{
Racial Capitalism, Slavery, Labour Regimes and Exploitation in the Canadian Seasonal Agricultural Workers Program
}

Julie-Ann McCausland

\section{Introduction}

This paper will attempt to critically examine Canada's Seasonal Agricultural Workers Program (SAWP) with an intent of connecting four themes: the Canadian agricultural industry, indentured servitude, the labour regime in Canada, and the racialization of the SAWP. It has been argued that the workers from the Caribbean who participate in the Temporary Agricultural Workers Program are should consider themselves fortunate to be given such an opportunity. I argue that this assertion is problematic because it overlooks the hardship the workers face in Canada as a result of their non-citizen status. I also examine the fact that many of the workers enlisted in the SAWP are forced to migrate for a living wage due to poor economic conditions in their countries of origin, and that these conditions are a direct consequence of unequal trade policies and structural adjustment programs. Finally, I demonstrate Canada's complicity in benefiting from these programs.

\section{The Canadian Agricultural Industry}

The SAWP is a temporary labour program that brings foreign workers to Canada for periods between six weeks and eight months annually in order to resolve labour shortages in the agricultural sector. As a result of this labour shortage, the Canadian government employed a variety of stop-gap measures during the period between 1945 and 1965 (Preibisch and Binford 9). While helping to ease the shortages, these measures upheld a decidedly racist immigration policy that denied temporary visas or permanent residence to people of colour (Preibisch and Binford 9).

A transnational approach to viewing the issues affecting migrant farm workers allows for a global perspective. To provide for themselves and their families, migrant farm workers were forced to painfully separate from their families and their communities for months every year and to lead temporary, transnational lives. For them, leading a transnational work life is not necessarily a luxury, a privilege, or an act of political resistance. It is a means to an end; it is survival (Hennebry 2). The UN Convention on the Rights of Migrants defines a migrant worker as a "person who is to be engaged, is engaged or has been engaged in a remunerated activity in a State of which he or she is not a national" (UNESCO; Hennebry 2). Those who migrate temporarily for work are typically referred to as "temporary labour migrants" or "overseas contract workers" and are generally defined as people who migrate for a limited period of time in order to take up employment and send home money. Accordingly, "migrant workers" have become an important labour resource in the global economy (Hennebry 2).

Many of the workers enlisted in the Canadian SAWP are forced to migrate for a living wage due to poor economic conditions in their native countries. As Professor Edmonds highlighter in one of his lectures, the poor economic conditions in these countries are attributed to globalization and global restructuring through Structural Adjustment Programs (SAPs) that are part of the requirement from international financial institutions such as the International Monetary Fund (IMF) and the World Bank. SAPs are policies pushed by the IMF and the World Bank in poor countries as conditions for receiving loans or for obtaining lower interest rates on existing loans 
(Edmonds). SAPs not only create unequal trade policies between countries such as Jamaica and the United States but also provide an unfair economic shift of responsibility from the corporations involved to the most vulnerable, e.g. farmers and the poor working class in Jamaica. Moreover, SAPs force the production of crops for their profitmaking value rather than for the benefit of the farmers, i.e. cash crops. (Edmonds). Therefore, workers accept poor employment conditions out of economic necessity and because of limited opportunities for social mobility in their home countries, as can be seen in countries as such as Mexico and Jamaica.

\section{Indentured Servitude}

In "Interrogating Racialized Global Labour Supply: An Exploration of the Racial/National Replacement of Foreign Agricultural Workers in Canada," Kerry Preibisch and Leigh Binford argue that the 1965 White Paper and the reformed immigration act passed in 1966 abolished the most racist clauses of the Indian Act, paving the way for the recruitment of Jamaican workers as well as workers from other Caribbean countries like Trinidad and Tobago and Barbados in 1968. This also allowed workers from Mexico to enter the Program in 1974 (Preibisch and Binford 9). Since its inception, the offshore program has grown continuously. In 1998, Ontario farming operations recruited 5,233 workers from Mexico and 6,937 from the Caribbean to work primarily as fruit, vegetable and tobacco pickers, but also in greenhouses, nurseries and canning factories. Growers in Simcoe, Tillsonburg, St. Catharines and Leamington each attracted more than 1,000 foreign seasonal workers in 1998 (Bauder and Cobin 2).

The majority of migrants are men from poor households, with little education and often in the position of supporting large families. The SAWP has been a resounding success for Canadian growers because offshore indentured workers enable agribusiness to expand and secure large profits. Being indentured means that migrant farm workers are bound to specific employers by contractual agreements for the duration of their contracts.

This set up and the regulations that accompany it result in a number of negative impacts on SAWP workers. First, they are legally prevented from unionizing. Consequently, they do not enjoy access to the same rights and protections as workers with status. Additionally, because they are bound to specific employers, they must ensure that the employer is happy with them so that they can keep their works. This ensures that foreign workers not only work hard, even when they are ill and/or injured, but also that they remain submissive. For instance, migrant farm workers are forced to agree to growers' requests for long working hours, labour through the weekend, suppress complaints and avoid conflicts, if they want to stay out of "trouble" and to be offered renewed employment the following season (Preibisch and Binford 10).

Indentured servitude has enabled a multimillion dollar enterprise for employers in the agricultural industry in Canada. SAWP workers have communicated clearly that being tied to specific employers makes it difficult, if not impossible, to seek out better workplaces. Consequently, employers are enabled to offer poor wages and inadequate working conditions. This system of unfair advantage essentially makes the migrant farm workers "unfree" (Chowdhury p.9).

\section{The Labour Regime in Canada}

Chris Ramsaroop, a labour advocate with Justice for Migrant Workers, argues that, besides the contract, this state of being unfree is reinforced through a climate of fear that is pervasive among the migrant farm workers community. That is, being temporary labour and tied to a specific 
employer has made migrants removable, replaceable and exploitable. The threat of expulsion and/or repatriation from the program prevents farm workers from protesting because the idea has been planted in their minds that if they do protest, they will be replaced by new migrant farm workers. This demonstrates that, in addition to being unfree, migrant farm workers are viewed and treated as disposable commodities.

Both growers and the Canadian Government have successfully instituted a labour regime in which migrant farm workers are continually exploited (Bauder and Cobin 4). In "Canada's Creeping Economic Apartheid", Grace Galabuzi shows that the Canadian Government's immigration policy is, in reality, a labour market immigration policy (Galabuzi). Under this immigration policy, migrants are allowed entry into Canada to serve a particular labour market need. In this sense, the labour market need is in the agricultural industry. It is worth noting that this need is different from other labour market needs in that it only requires additional labour for limited periods of time per year.

Existing policy suggests that employers in the agricultural industry view migrant farm workers as "matter-of-fact features" of the industry as well as economic elements and "insurance policies" for the prosperity of the Canadian economy (Bauder and Cobin 7), with little consideration for the needs of the actual workers. For example, the importance of migrant farm workers for Canada's continued economic stability is often conveyed in quotes from growers suggesting that "our industry wouldn't survive without them" (Bauder and Cobin. 7). The focus is on the Canadian perspective, and not on mutual benefit. Moreover, by using the term "them," the grower creates a distinction, othering them as different from "us". According to Audre Lorde, this distinction of difference is an absolute necessity in a profit economy that relies on outsiders as surplus people (Lorde 118). This lack of concern for the workers strengthens the view that migrant farm workers are essentially "unfree" in Canada.

\section{Racialization of the Seasonal Agricultural Workers Program}

In "Globalization and the Mexican-Canadian Seasonal Agricultural Worker Program: Power, Racialization \& Transnationalism in Temporary Migration," Jenna Hennebry argues that the SAWP participates in the processes of racialization and the unequal treatment of non-European groups, even though the program was meant to improve the prosperity of both Canadians and migrant farm workers (Hennebry 59). For example, public discourse in the early 1960s suggested that Caribbean workers were not biologically suited for the climatic conditions of Canada and, therefore, that they would be unable to live in Canada year round. It was also purported that, if migrant farm workers were allowed to immigrate, they would "create racial problems" in Canadian communities (Hennebry 59). Hence, migrant farm workers could only be admitted as temporary workers under strict mobility and employment constraints (Hennebry 59-60). Migrant workers were presented in a manner that portrayed them as racially inferior and better suited than Canadians for strenuous, seasonal farm work.

In a similar vein, an article by Harald Bauder and Margot Corbin, "Foreign Farm Workers in Ontario: Representations in the Newsprint Media," surveys media narratives about migrant farm workers in Ontario daily newspapers between the years 1996 and 2002. The results show that the media depicted migrant farm workers as "Others" in Canadian society. MThe articles also made connections between migrant farm workers and crime, implying that there is a structural link between workers recruited under the offshore program and criminal behavior (Bauder and Cobin $10)$. 
In another study, Yasmin Jiwani demonstrated that the media contributes to demonization of racialized persons by identifying their racial background when sharing the information is simply not warranted (5). Jiwani characterizes this representation as "mediated racism." Mediated racism functions in several ways, the most obvious being through the association of specific groups of people with specific actions (4). This parallels Henry Giroux's argument that the public's preoccupation with linking people of colour with violence and crime is encouraged by the media's narrative framing (177). As further stated by Jiwani, the continual linking of people of colour to crime is largely due to the underrepresentation of people of colour in the media, as only $2.6 \%$ of people employed in major dailies in Canada are people of colour (5). Therefore, it is not surprising that newspaper articles tend to reflect the public's preoccupation with criminal behavior and people of colour. The perceived threat of racialized persons results in a public preference for migrant workers to be employed and housed in rural communities where they are secluded and their activities are limited to labour activities on the farm. The public's fear is exacerbated by the media's language, leading to the raising of cultural barriers that contribute to the segregation of migrant farm workers in host communities. In addition, migrant farm workers are not in a position to influence governments, employers, and other intermediaries who have significant control over their daily lives or the parameters of their migration (Hennebry 2006, 3).

In "When place becomes race," Sherene Razack contends that a racial hierarchy exists in Canada. This racial hierarchy is built on the foundation of "white settler society." White settler society is based on the myths created by white settlers in order to establish their claim that the lands they colonized and settled on belong exclusively to them (Razack 3 ). In a Canadian context, part of the mythology claims that white settlers came to Canada and shared the land equally with the Indigenous inhabitants and that, after, these settlers singlehanded developed the land, essentially making it theirs over time. Over time, the myth developed to protect the interests of white settler in the face of more recent migrations into the country. Now, white settlers view themselves as the original inhabitants of Canada, whose benevolence in opening up their doors is being taken advantage of by third-world refugees and migrants who threaten overwhelm them (Razack 4). These mythologies, coupled with the mediated racism, have been used to further construct migrant farm workers as "Others" in Canadian society.

Likewise, the segregation of migrant farm workers who are confined to the farms on which they work speaks to their isolation from Canadian society. Notably, geography is an essential tool in the construction of racial hierarchies (Razack 7). The space in which migrant farm workers are housed becomes a one "shaped by capitalism in a class system" (Razack 8). Migrant farm workers are confined to rural communities where contact with white settler society is limited. When they do cross the boundaries into white settler societies, they are often harassed or, worse, assaulted by white Canadians (Bauder and Cobin 18).

Compounding their grievances, growers and others consider Mexican workers "closer" in appearance to the Canadian population, which "naturally" makes them more desirable workers (Preibisch and Binford 29). For example, one administrator commented that the concentration of Mexican workers in Leamington was due to the "closer association" between Mexicans and the region's Southern European-origin growers (Preibisch and Binford 29). Employers also face community pressure to hire "Brown" (Mexican) workers as opposed to "Black" (Caribbean) workers because Mexican workers, are closer in complexion to the White Canadians and therefore more acceptable (Preibisch and Binford 29). Consequently, racism is clearly illustrated in the communities' as well as the growers' concerns with Black Caribbean workers. 
Little attention has been given to the issues and right protections for migrant farm workers. For this reason, it is hard to conclude a conversation on the racialization of the SAWP without mentioning the work of Chris Ramsaroop and Gabriel Alladua of the advocacy group, Justice for Migrant Workers, for the assistance they have been giving to the migrant farm workers community. Justice for Migrant Workers (J4MW) is a voluntarily established group that aims advocates for non-status workers who enter Canada through the SAWP. To achieve its mission and goals, the organization educates workers about their rights and creates spaces for workers to dialogue free of repercussions (Lecture. March 15, 2018). The primary mission of J4MW is to highlight the invisibility, marginalization of and discrimination against migrant farm workers, and to connect the struggles of the workers with the processes of globalization, structural adjustment, rural displacement and how they relate to the apartheid system that still exists in Canada.

The organization does this by encouraging migrant farm workers to organize amongst themselves to achieve equality. Unfortunately, in our lecture of March 15, 2018, the presenter, Chris Ramsaroop, did not delve into the issue of advocacy for equitability for female migrant workers. It would have been especially interesting in light of the 199 women that were employed in the SAWP in 2003 and the 227 who were employed in 2004. The lack of clear representation of the plights of female migrant workers is what Suzan Archer Mann describes as the "hierarchicalization of oppression" in her article on simultaneous and multiple oppressions, where one from of oppression is treated as more fundamental than the other (Mann 2). Nevertheless, the organization is important because of its transnational nature. It considers the economic strains of sending migrant workers from countries such as Jamaica and Mexico to Canada, as well as Canada's complicity in benefiting from the poverty in these countries. The J4MW stresses its most important work involves considering the families left behind by migrant farm workers.

\section{Conclusion}

While the SAWP officially aims to improve the economic prosperity of both Canada and the migrant workers, the program also operates under a labour regime a processe of racialization that contribute to the unequal treatment of migrant farm workers. Hennebry's research on the SAWP demonstrates that migrant farm workers are particularly valuable to capitalist accumulation due to their restricted freedom and relative powerlessness in the agricultural industry in Canada (Hennebry 59). Moreover, Canada's complicity in benefiting from the program can be attributed to the fact that SAWP provides Canadian employers with easy access to marginalized labour from Third World countries. For example, foreign workers grew to $52.4 \%$ of the labour force and supplied $45 \%$ of total hours in 2000 in the two provinces hiring $90 \%$ of the workers: Ontario and Quebec (Preibisch and Binford 10). Furthermore, we saw how notions that migrant farm workers were not biologically suited for the climatic conditions of Canada have been used as a labour strategy for denying migrant farm workers their rights and a path to permanent residency. These are evidence of the racialization of the program and labour regime used to continually exploit migrant farm workers in Canada. The idea that foreign labour is racially inferior assumes that foreign labour is best suited for the primitive, labour-intensive work required on farms. This flawed reasoning legitimizes the constraints of workers' freedom and the poor working conditions under which they toil.

Migrant farm work is viewed as a personal choice, and the workers are seen as fortunate. 
This, of course, does not take into consideration the families that are left without a child, parent, partner or sibling for part of the year. It also neglects the emotional turmoil caused by separation. Additionally, migrant farm workers must endure a lack of control over the duration of their contracts, an absence of overtime pay, a high level of social isolation and virtually no possibility of obtaining permanent residency in Canada (Preibisch and Binford 10).

Certainly, workers benefit from their seasonal employment in Canada despite the harsh working conditions. The wages paid in Canadian dollars allow farm workers to pay for better education for their children and provides the opportunity for social and economic mobility in their countries of origin. However, the workers' enrolment in the SAWP is more often than not a compelled choice rather than an enthusiastic one. It is largely due to the gap between rich countries, such as Canada, and poor countries, such as Jamaica. It is a form of coercion that pushes ThirdWorld people to seek work in the First-World countries for lack of options closer to home. Thus, it is not a matter of being fortunate, but of a lack of more lucrative options. 


\section{Works Cited}

Bauder, Harald \& Corbin Margot. "Foreign Farm Workers in Ontario: Representations in the Newsprint Media.

Chowdhury, Fariah (2012). Turning Factory Floor and Farm Fields into Sites of incarceration: Unmapping the Production of Deportability through Canadian Immigration Raids. Excerpt: Unpublished MA Thesis. University of Toronto.

Edmonds, Kevin. "The Global Plantation: Migrant” Farm Workers In Canada". Lecture March 15, 2018.

Galabuzi, Grace-Edward (2001 May). Executive summary in Canada's creeping economic Apartheid: The economic segregation and social marginalization of racialised groups. Toronto: The Centre for Social Justice (pp. 3-5).

Justice for Migrant farm workers: http://justicia4migrantworkers.org/justicia_new.htm

Lorde, Audre (1984). Excerpt from, Age, race, class and sex: Women redefining difference. In, Audre Lorde, Sister Outside: Essays and Speeches by Audre Lorde (pp. 115). Berkeley. The Crossing Press.

Mann, Susan Archer. "Simultaneous and multiple oppressions. In Doing Feminist Theory: From Modernity to Postmodernity." (2012): (pp. 178-180). New York: Oxford Press.

Preibisch, Kerry and Binford, Leigh (2008) 'Interrogating Racialized Global Labour Supply: An Exploration of the Racial/National Replacement of Foreign Agricultural Workers in Canada,' Canadian Journal of Sociology, 44(1), pp. 5-36

Razack, Sherene H. (2002). Excerpt from Introduction: When place becomes race. In S.H. Razack (Ed.), Race, space and the law: Unmapping a white settler society (pp. 1-15). Toronto: Between the Lines.

Yasmin, Jiwani (2016): Racism and the Media: http://www.stopracism.ca/content/racism-and$\underline{\text { media }}$

Zach Ruiter. (2016) “Migrant Workers Say They're Canada's Modern Day Slaves”. Toronto Now. September 27. Available at: https://nowtoronto.com/news/migrant-workers-canada\%27s-modernday-slaves/ 